\title{
No healing without recognition: a review of Mark McKenna's Moment of Truth
}

\author{
Aryan Golanjan \\ University of Technology Sydney, Faculty of Arts and Social Sciences, PO Box 123, Ultimo NSW \\ 2017, Australia. aryan.golanjan@student.uts.edu.au
}

DOI: https://doi.org/10.5130/nesais.v4i1.1507

In late 2017, between the furore of the Commonwealth citizenship saga, Malcolm Turnbull quietly rejected the Uluru Statement from the Heart; a statement borne from days of deliberation between Indigenous leaders from across Australia as part of the Referendum Council. The statement called for constitutional reform enshrining the establishment of a 'First Nations Voice', a Makarrata Commission and, importantly, a treaty (Referendum Council 2017). It is with a blistering critique of Turnbull's choice to reject the statement that Issue 69 of the Quarterly Essay, titled Moment of Truth (McKenna 2018), opens. Mark McKenna traverses modern Australia, drawing upon historians, academics, advisory bodies, and personal narratives to consider the role that both white and Indigenous history have had in forming today's nation, delving into the erasure of key moments in Australia's past and confronting our past and current violence towards Indigenous peoples.

McKenna discusses the culture and history of Indigenous Australia, told in ways that attempt to overcome the revisionism of European settler narratives. These narratives have erased Indigenous voices and perspectives, reducing invasion to 'settlement', removing the frontier wars from the national record, and failing to centre Indigenous voices in stories of forced removals, war, and survival. Throughout the essay, McKenna reveals a fragmenting in the Australian psyche, with a fear of confronting the past and seeing a truer, more 'whole' history (2018, p. 16). The Australian psyche in itself is portrayed as an invention borne only from the genocide of Aboriginal peoples leading to the development of 'modern' Australian society, and the failure to confront this concomitance is decried (Stanner 1977, pp. 23-24). McKenna's historical and socio-political analysis forces us to confront the stark divide that our country now faces and ask ourselves why the situation remains so stagnant. Constitutional recognition, treaty and provision for a voice to Parliament are not merely symbolic to Indigenous people, but are significant and tangible; after centuries of colonial inhabitation, it is time for the First Peoples of this nation to feel as though they have a proper and rightful place in their ancestral lands (Pearson 2014, p. 7).

The erasure of Indigenous voices from Australian history has led to the peddling of many falsehoods; McKenna masterfully rebuts many widely held beliefs by actively searching for and including the voices of Indigenous people, including historical accounts of European invasion and colonisation. He 
argues that perhaps one of the least well-known moments in Australian history is the frontier wars and the massacres of Aboriginal people that came with it; this aspect of history has not yet made its way into the collective national consciousness (McKenna 2018, pp. 37-38). By publishing the words of Indigenous people present during the crimes, McKenna subverts the colonial representations of Indigenous people. As this same colonial mythology of Indigenous 'otherness' fuelled the massacres, rewriting the fictional European narrative to display a more complete reality removes the hegemonic dehumanisation of Indigenous people (Morris 1992, pp. 86-87). It is this dehumanisation that academics have deemed the "profoundest moral problem of this history", as the mass murder of Indigenous people posed no moral qualms, and in many retellings of this history, has not been provided with the gravity that it deserves (Pearson 2014, pp. 19-21). The inclusion of Indigenous voices or even the mere placement of Indigenous people at the centre of narratives involving them can prevent the ongoing dissemination of falsehoods of the like that have occurred since invasion, and indeed, regarding invasion itself. For example, although the popular representation of Captain Cook's Botany Bay landing is that of a fraught contest between the original inhabitants of the land and the invaders, the examination of records and oral histories of Cook and Indigenous Australians reveals an entirely different story (Nugent 2008, pp. 203-206).

It is not merely the telling of Indigenous history that McKenna explores, however. Instead, he attempts to bring this history into the mainstream Australian consciousness and reconcile it with the historical perspective that has formed our dominant narrative. This is clearest when he travels to Kurnell, where a signpost stating, 'Welcome to the birthplace of modern Australia' greets him (McKenna 2018, p. 48). We learn that the sign has had a fraught history, undergoing revisions from its initial 'birthplace of Australia', to 'birthplace of the nation', to finally, following the 'White Australia has a Black history' campaign in 1988, the current greeting. In response to those who critique the campaign to change the date of Australia day or remove statues of Captain Cook in places like Hyde Park on the basis that this is 'revising history', McKenna argues that this revision at Kurnell is no different, that reconsidering the past as new knowledge comes to light should be second nature (2018, p. 51). What he does not say is that white Australia has been revising history for centuries; that there was no consent when Cook arrived on the shores of Kurnell, that there was no choice or freedom afforded to Indigenous inhabitants when violent colonisation occurred (Pearson 2014, pp. 42-44), that white Australians have told their stories, forming a dominant national narrative, whilst Indigenous voices have been relegated to the wayside.

The importance of collaborating on histories in order to prevent further divisiveness in the Australian cultural psyche cannot be overstated; without this, contradictory and simplified 'facts' will continue to be propagated (Goodall 2002, p. 24). McKenna recognises this, but notes rightly that the Australian state and legislature lag far behind on the simplest of tasks: mere recognition of this nation's First Peoples. He calls for a "more complete Commonwealth", one where the demands of the Referendum Council are not met with silence, where violent dispossession is confronted, where the "change the date' campaign is not accused of attempting to rewrite history. Within the Parliamentary Triangle is one of the places the absence of an Indigenous voice is most keenly felt, after a 2014 federal government committee recommendation that a National Keeping Place dedicated to Indigenous ancestral remains with unknown origin be built there, as well as a National Memorial for the frontier wars (Advisory Committee for Indigenous Repatriation 2014). It is both symbolic and more tangible, legislative acts that must be taken to move towards recognition of our shared history. 
To combat the silence he has identified through a socio-political analysis of histories, McKenna proposes a concept that seems radically simple: truth-telling. He posits that the challenge of reconciliation is not merely the reconciliation of Indigenous and non-Indigenous Australians, but the competing histories, identities, and sense of nationalism that has come to the fore. To appreciate and overcome our alienation from the violent history of this country, the truths of Indigenous Australians must be heard and woven into the fabric of Australia's mainstream consciousness. Only then will we fulfil the spirit of Makarrata - "healing and coming together after a struggle".

\section{References}

Advisory Committee for Indigenous Repatriation 2014, National Resting Place: Consultation Report, Department of Communication and the Arts, Canberra.

Goodall, H. 2002, 'Too early yet or not soon enough? Reflections on sharing histories as process', Australian Historical Studies, vol. 33, no. 118, pp. 7-24. https://doi.org/10.1080/10314610208596176

McKenna, M. 2018, 'Moment of Truth: History and Australia's Future,' Quarterly Essay, no. 69, pp. $1-86$.

Morris, B. 1992, 'Frontier colonialism as a culture of terror', Journal of Australian Studies, vol. 16, no. 35, pp. 72-87. https://doi.org/10.1080/14443059209387119

Nugent, M. 2008, 'The encounter between Captain Cook and Indigenous people at Botany Bay in 1770 reconsidered', in Veth, Sutton and Neale (eds) Strangers on the Shore: Early coastal Contacts in Australia, Canberra ACT, National Museum of Australia Press, pp 198-207.

Pearson, N. 2014, 'A Rightful Place: Race, Recognition and a More Complete Commonwealth', Quarterly Essay, no. 55, pp. 1-72.

Referendum Council 2017, Final Report of the Referendum Council, Department of the Prime Minister and Cabinet, Canberra.

Stanner, WEH. 1977, 'The History of Indifference Thus Begins', Aboriginal History, vol. 1, pp. 3-26. 